\title{
Ocalająca moc literatury i sztuki - analiza powieści Jak ziarnka piasku Joanny Jagiełło w świetle biblioterapii i arteterapii
}

\section{Abstrakt:}

Artykuł jest próbą biblioterapeutycznego odczytania utworu Jak ziarnka piasku Joanny Jagiełlo (2018) w oparciu o założenia teoretyczne zaprezentowane przez Irenę Borecką oraz Danutę Gostyńską. Autorka wykorzystuje także pojęcie Pokolenia Nikt ukute przez Grzegorza Leszczyńskiego w odniesieniu do pokolenia schyłku XX wieku. Dowodzi, że lektura omawianej książki może okazać się pomocą dla nastolatka, który doświadczył śmierci bliskiej osoby - powieść pozwala czytelnikowi utożsamić się z narratorką (i jednocześnie protagonistką) historii i oferuje drogi wyjścia z trudnej sytuacji. Autorka zwraca także uwagę na terapeutyczną moc sztuki - opierając analizę na założeniach Eweliny J. Koniecznej o arteterapii - oraz wskazuje na potrzebę oswajania i przełamywania tabu śmierci poprzez literaturę młodzieżową.

Słowa kluczowe:

arteterapia, biblioterapia, Jak ziarnka piasku, Joanna Jagiełło, polska literatura młodzieżowa, Pokolenie Nikt, śmierć, tabu

\section{A Rescuing Power of Literature and Art -} Analysis of the Novel Jak ziarnka piasku by Joanna Jagiełło in the Light of Bibliotherapy and Art Therapy

\section{Abstract:}

This article is devoted to the bibliotherapeutic analysis of the novel Jak ziarnka piasku [Like Grains of Sand] by Joanna Jagiełło (2018). The reflections made in the article are accompanied by theoretical assumptions of Irena Borecka and Danuta Gostyńska, and an actualisation of the term 'Nobody Generation,' proposed

* Natalia Morawska - lic., przygotowuje pracę magisterską na Wydziale Polonistyki Uniwersytetu Warszawskiego dotyczącą motywu ożywionej lalki w literaturze dziecięcej i młodzieżowej na podstawie wybranych dzieł dla najmłodszych i nastoletnich czytelników. Studiuje w Instytucie Historii Sztuki Uniwersytetu Warszawskiego. Kontakt: n.morawska@student.uw.edu.pl. 
by Grzegorz Leszczyński in reference to the generation of the end of the $20^{\text {th }}$ century. The author of the paper demonstrates that reading the book might be helpful for a teenager who experienced the death of a loved one - it allows the reader to empathise with the story's narrator (who is also its protagonist) and offers ways to deal with tough situations. The author also points out that the book deals with the therapeutic role of art - she carries out the analysis based on Ewelina J. Konieczna's assumptions about art therapy - and shows how important it is to get used to death and to breake the death taboo through young adult literature.

Key words:

art therapy, bibliotherapy, Jak ziarnka piasku, Joanna Jagiełło, Polish young adult literature, Nobody Generation, death, taboo

\section{Wprowadzenie. Pokolenie Nikt - zagubieni w labiryncie cierpienia}

$\mathbf{P}$ olska proza młodzieżowa schyłku XX wieku przyniosła ze sobą problemy wcześniej nieporuszane, występujące jedynie marginalnie w naturalistycznych i realistycznych powieściach dla dorosłych. By bliżej przyjrzeć się temu zjawisku, sięgnę do rozważań Grzegorza Leszczyńskiego (2010), który w książce Bunt czytelników. Proza inicjacyjna netgeneracji kreśli dogłębny obraz Pokolenia Nikt - wyłaniający się z literatury portret generacji końca XX wieku. Parafrazuje przy tym tytuł słynnej Panny Nikt Tomka Tryzny (1994): „Jest to - jak dowodzi lektura [wspomnianej powieści] - pokolenie pozbawione zakorzenienia i poczucia tożsamości, psychicznie i duchowo bezdomne, pokolenie szukające tzw. mocnych wrażeń, których dostarczają alkohol, narkotyki i wolny od miłości seks" (Leszczyński, 2010, s. 17).

W kontrze do przywołanego wyżej utworu, jako opozycyjny model powieści inicjacyjnej przełomu XX i XXI wieku, badacz umieszcza (wydawaną od lat 70. ubiegłego stulecia, wciąż kontynuowaną) Jeżycjadę Małgorzaty Musierowicz. Wskazuje, że utwory obecne po „stronie Musierowicz” nie wystrzegają się powszechnie rozumianego dydaktyzmu, pouczeń, które błądzący, młody człowiek otrzymuje od rodziców oraz nauczycieli, i to właśnie dzięki nim zawsze znajduje wyjście z kryzysowej sytuacji (Leszczyński, 2010, s. 64). Dzieła ze „strony Tryzny” natomiast odcinają się od wszelkich nauk, pokazując, że:

Drogi, które wydawały się jasnymi traktatami, prowadzącymi w pożądanym kierunku, okazują się ślepymi zaułkami. Poznane wcześniej przejścia zostały zamurowane. Wyuczone, zapamiętane i zinterioryzowane wzory zachowań nieoczekiwanie zawodzą w sytuacjach granicznych. Reakcją młodego bohatera 
jest paniczny lęk przed życiem, w którym wszystkie wartości stały się względne, a prawdy - bezużyteczne (s. 64).

Zarówno w lekturach lokujących się po „stronie Musierowicz”, jak i w dawnym, XIX-wiecznym, klasycznym modelu powieści dla młodzieży, bohater bez większych problemów, zwycięsko pokonywał przeszkody, jakie stawiało przed nim życie (s. 26-27) - opierał się przy tym na autorytetach, takich jak: dom, rodzina, szkoła, Bóg, wiara. Reprezentant Pokolenia Nikt pozostaje ze swoimi problemami osamotniony, nie szuka oparcia w tradycyjnej hierarchii wartości, jak również nie ma jasnych punktów odniesienia: „Rodzina nie daje młodemu człowiekowi elementarnego poczucia bezpieczeństwa", dom nie zawsze jest bezpieczną oazą - dla niektórych przemienia się on w źródło bólu, samotności, przemocy (s. 28). Nawet przyjaźń czy miłość bywają przyczyną cierpienia, co prowadzi dodatkowo do podkreślenia niemożności nawiązania trwałych relacji międzyludzkich, które dawałyby oparcie i wyzwalałyby z samotności.

Warto podkreślić, że ukuty przez badacza termin „Pokolenie Nikt” nie odnosił się do żadnej rzeczywistości społecznej - został użyty jedynie jako literacka kategoria w odniesieniu do dzieła Tryzny oraz innych powieści o podobnej tematyce. Choć Leszczyński odwołuje się do lektury pokoleniowej, liczącej już prawie trzydzieści lat od momentu wydania, sądzę, że omawiane pojęcie oraz przywołane przez autora refleksje nie tracą na aktualności, a wskazany termin można zastosować przy opisie zjawisk obecnych i w drugiej dekadzie XXI wieku w literaturze dla współczesnych nastolatków - kolejną generację nadal reprezentują ludzie zagubieni, poszukujący własnej tożsamości, często niemający żadnych punktów oparcia w postaci nauczycieli, rodziny, bliskich. Przy tym wszystkim można rzec, że literacki obraz Pokolenia Nikt uległ pogłębieniu $^{1}$ - nieobce staje się mówienie o problemach określanych wcześniej mianem

1 Wszechobecna dla nastoletnich czytelników stała się również komunikacja internetowa, głównie poprzez media społecznościowe. Pojawiły się też nowe tematy wychodzące ze sfery tabu, jak niezwykle aktualny problem chorób psychicznych, depresji u młodzieży, kwestia homofobii i transfobii, prześladowania i szykanowania ze strony rówieśników, mowy nienawiści - np. w reportażu Aleksandry Szyło (2015) czy spektaklu $h$. w reżyserii Daniela Stachuły (2019) - a także zjawisko cyberprzemocy wśród nastolatków (co ukazuje m.in. najnowsza kampania społeczna Stowarzyszenia SOS Wioski Dziecięce i NASK, zatytułowana Niewidzialna przemoc, ogłaszana w mediach pod hasłem: „Przemoc w internecie zostawia niewidzialne rany"). Sądzę, że tym samym można mówić już nie o pokoleniu netgeneracji, ale bardziej o pokoleniu, dla którego świat internetu, jego języka oraz social mediów, stał się codziennością, drugim, współistniejącym światem, przestrzenią - często niebezpieczną - do wymiany wszelkich poglądów. W opracowaniach badaczy (Twenge, 2017/2019; Wiktorowicz, Warwas, 2016) funkcjonują takie propozycje terminologiczne na 
tabu, takich jak: przemoc w rodzinie, wykorzystanie seksualne, choroba (w tym problem niepełnosprawności), śmierć, samobójstwo czy depresja ${ }^{2}$. Tematy te stają się wszechobecne w dzisiejszej prozie dla młodzieży, choć podejmowane są w różny sposób (wystarczy spojrzeć na tytuły książek wydanych w ostatnich kilku latach ${ }^{3}$ czy nawet na najnowsze filmy i seriale młodzieżowe, w tym ekranizacje powieści ${ }^{4}$ ). Próbuje się je $\mathrm{z}$ tabu odzierać, oswajać $\mathrm{z}$ nimi odbiorców; sądzę jednak, że w poruszających te zagadnienia tekstach wciąż brakuje przykładowych rozwiązań, nie oferuje się dróg wyjścia z trudnych dla młodego człowieka sytuacji ${ }^{5}$, a przede wszystkim - brakuje wsparcia i pocieszenia. Skoro np. w ostatniej dekadzie tak wiele mówi się o potrzebie poruszania tematu

określenie dzisiejszych nastolatków jak „pokolenie Z”, „iGen”, „iGeneracja” czy „pokolenie xD” - określenie oddające język młodzieży. Komunikacja internetowa jest zresztą nieobca bohaterom analizowanej przeze mnie powieści, ale już na początku lektury rola mediów społecznościowych wybrzmiewa tragicznie - Nina relacjonuje swoją samobójczą śmierć, publikując na Facebooku nagranie na żywo.

2 Szerzej o tych i innych problemach w kontekście literatury młodzieżowej pisali m.in. Dominik Borowski (2014, 2016), Alicja Fidowicz (2020a, 2020b) i Dorota Michułka (2018). Na wzmożoną obecność literatury młodzieżowej dotyczącej trudnych, często drastycznych tematów na współczesnym polskim rynku książki zwrócił też uwagę Michał Rogoż (2019). Dawniej taka tematyka, jeśli już się pojawiała, była ledwie sygnalizowana: „[...] obrazy przemocy wobec dzieci pojawiały się jedynie w literaturze dla dorosłych, a i to nadzwyczaj rzadko" - pisze Leszczyński (2010, s. 33), a jako przykłady podaje (s. 33-34) m.in. opowiadania Marii Konopnickiej (1890/1974), Halucynacje Ludwika Stanisława Licińskiego (1911/1978) oraz Dziecko salonu Janusza Korczaka (1906/1980). Warto wspomnieć za badaczem (Leszczyński, 2010, s. 22), że problem młodości jako cierpienia, bólu adolescencji, jako pierwszy w literaturze dziecięcej podjął w Spowiedzi motyla właśnie Korczak (1914/2018).

3 Na uwagę zasługują z pewnością: najnowsza, uhonorowana nagrodą Książka Roku 2020 Polskiej Sekcji IBBY powieść Orkan. Depresja Ewy Nowak (2020), trzy powieści Jagieło (kolejno 2016, 2018, 2020): Zielone martensy, Jak ziarnka piasku (książka omawiana w tym artykule, również nagrodzona nagrodą IBBY) i To już nie ma znaczenia, Czarne Jeziora Doroty Suwalskiej (2016, wyróżnienie w konkursie IBBY) czy też powieści Marty Fox; z dzieł zagranicznych - np. Wszystkie jasne miejsca Jennifer Niven (2015) lub przykładowe książki Johna Greena (kolejno 2005/2007, 2012/2013), Szukając Alaski oraz Gwiazd naszych wina.

4 Więcej o młodzieżowych filmach i ukazywanych w nich problemach pisze Leszczyński (2010, s. 65-81) we wspomnianym studium o pokoleniu netgeneracji. Na uwagę zasługuje też wielość ekranizacji skierowanych do młodzieży (w tym adaptacji zagranicznych powieści młodzieżowych) dystrybuowanych w ostatnich latach przez platformę streamingową Netflix (zob. np. Jakubowski, 2020).

5 Wciąż aktualne wydają się słowa Leszczyńskiego (2010): „W klasycznej prozie dla młodzieży bohater reprezentujący swą generację był panem świata i siebie, królem życia. Owszem, natrafiał na przeszkody, ale potrafił pokonać je skutecznie i zwycięsko [...]. Współczesny nastoletni bohater ma świadomość niemożliwości dokonania zmian w jakiejkolwiek sferze, jest nie tyle królem życia, ile raczej tego życia niewolnikiem, porzuconym w byle jakim 
śmierci wśród najmłodszych (Slany, 2018; Wolszczak, 2018) ${ }^{6}$, a przełamywanie strachu przed śmiercią nieobce jest również literaturze dla osób starszych (co ukazuje biblioterapia reminiscencyjna - Borecka, 2001; Dudzikowska, Tomasik, 1998, s. 279-280, 283; drugie z opracowań przywołane za: Konieczna, 2003, s. 115), dlaczego nie oswaja się z tą tematyką również nastolatków? Może przyczyną jest to, że młodzi dorośli ${ }^{7}$ znajdują się gdzieś pomiędzy dzieciństwem a dorosłością? Może zakłada się, że śmierć jest konieczną i dosadną inicjacją, która prędzej czy później musi nastąpić, i wciąż uznaje się ją za temat tabu? Nawet jeśli już ten problem pojawia się w powieściach, to $\mathrm{w}$ wielu utworach czy telnik pozostawiony jest sam sobie z całym tragizmem sytuacji, z otwartym zakończeniem - bez czytelnego rozwiązania i z wieloma niedopowiedzeniami. Obrazują to np. powieści Gra w śmierć Stefana Casty (1999/2007) czy Szukając Alaski Johna Greena $(2005 / 2007)^{8}$. W rezultacie młody człowiek, podobnie jak

miejscu historii, w byle jakim domu, w byle jakiej szkole, na byle jakiej ulicy, kiedykolwiek i gdziekolwiek" (s. 26).

6 Kryje się za tym m.in. potrzeba wskazywania na wychowawczą i - przede wszystkim - terapeutyczną funkcję literatury tanatologicznej, która ma za zadanie oswoić z tematem tabu zarówno dorosłego (by umiał rozmawiać z dzieckiem o śmierci), jak i młodego czytelnika. Pisała o tym m.in. Bernadeta Niesporek-Szamburska (2017), wskazując na długi czas pomijania tematyki śmierci w utworach dla najmłodszych: „Był okres XIX-wiecznej otwartości w przedkładaniu dzieciom kwestii śmierci, a nawet czas straszenia nią, następnie zaś okres »ograniczenia i łagodzenia scen śmierci w utworach dla dzieci« związany z pedagogicznymi nurtami odchodzenia od autorytarnych systemów pedagogicznych, a sprzyjający - od początków XX wieku - pozytywnym doświadczeniom dziecięcym, także literackim [...]. Po długim czasie pomijania tematów ostatecznych »oswajanie człowieka, w tym także dziecka, z zagadnieniem śmierci przez otwarte uczynienie jej przedmiotem poznania, dyskursu i akceptacji, ukazanie jej religijnych, filozoficznych i mitologicznych aspektów stało się jedną z ról literatury" (s. 98; cyt. wewn. - Papuzińska, 2002, s. 384).

7 Ang. young adults [młodzi dorośli] to termin przyjęty na określenie grupy wiekowej pomiędzy 12. a 18. rokiem życia, choć - jak podaje Michael Cart (2017, s. 272) - współcześnie to pojęcie jest stosowane również w kontekście 20-, a nawet 30-latków. Jako pierwsza wyodrębnienie grupy young adults postulowała Sarah Trimmer (Rogowicz, 2017, s. 90). Problematyczną kwestią jest jednak wydzielenie granicy między dzieciństwem a nastoletniością oraz włączanie przez niektórych badaczy literatury młodzieżowej w ogół literatury dziecięcej (Skowera, 2017, s. 14-15). W niniejszym tekście będę posługiwać się wymiennie terminami: „młodzież”, „młodzi dorośli” i „nastolatkowie”.

8 Przykładowo finał Szukając Alaski może nie być dla czytelnika w żaden sposób pokrzepiający - życie bohaterów po śmierci przyjaciółki toczy się dalej, utwór ma otwarte zakończenie. Pozostaje jednak pytanie, czego społecznie powinno się oczekiwać od literatury. Czy powinna w sposób realistyczny, a czasem wręcz dosadny, ukazywać rzeczywistość, taką jaka naprawdę jest (por. zakończenie powieści Orkan. Depresja autorstwa Nowak), czy też może powinna być rodzajem ucieczki od tej niekiedy brutalnej rzeczywistości? 
bohaterowie Greena, błądzi w labiryncie cierpienia i nie wie, jak się z niego wyzwolić 9 .

Z podobnymi problemami i próbą odcięcia ich od tabu mierzy się także powieść Jak ziarnka piasku Joanny Jagiełło (2018). W przeciwieństwie do wspomnianych wyżej utworów lektura ta oferuje czytelnikowi pewne terapeutyczne rozwiązania (takie jak arteterapia i dogoterapia), co zostanie ukazane w tym artykule. Należy jednak zaznaczyć, że odszukanie odpowiedniej drogi wyjścia z trudnej sytuacji ma indywidualny wymiar (Borecka, 2001, s. 22) i trudno mówić tu o skuteczności danych rozwiązań w każdym przypadku (pewne rozwiązanie może okazać się krzepiące dla młodego odbiorcy, jeszcze inne - dla rodzica, nauczyciela bądź terapeuty). W kontekście przedstawionej w powieści sytuacji żałoby po śmierci bliskiej osoby, hipotetyczny czytelnik, na przykładzie głównej bohaterki, dostrzega, że znalezienie ukojenia następuje z czasem; jest to pewien proces zmagania się z trudnościami oraz poszukiwania rozwiązania (obrazuje to również przyjęty przeze mnie podział artykułu na całostki, który zaprezentuję dalej).

Powieść opowiada o dwóch nastoletnich przyjaciółkach będących ze sobą w niezwykle bliskich - wręcz siostrzanych - relacjach, znających się od najmłodszych lat; choć dzielą zainteresowanie sztuką, są zupełnie różne: pochodzą z odmiennych domów, rodzin, szkół. Przyjacielską idyllę burzy moment samobójczej śmierci Niny, w wyniku czego Anna pozostaje sama. Próbuje poradzić sobie ze stratą i żyć dalej, ale nie może zapomnieć miejsc i wyzwolić się ze wspomnień związanych z przyjaciółką, nie potrafi pogodzić się z jej nagłym i niespodziewanym odejściem. Temat śmierci pojawia się zresztą nie tylko w kontekście wspomnianej sytuacji (choć jest ona osią powieści), a inne problemy, które porusza dzieło, to m.in. przemoc w rodzinie oraz wykorzystanie seksualne. Na szczególne znaczenie drugiej z tych kwestii przy odbiorze powieści zwracała uwagę sama Jagiełło ${ }^{10}$.

9 „Jak wydobyć się z [...] labiryntu cierpienia?” to pytanie, które zadają bohaterowie Szukając Alaski, wspomnianej już książki Greena (2005/2007, s. 189).

10 Warto wspomnieć, że pisarkę zainspirował m.in. reportaż o przemocy seksualnej wobec dziewcząt. Historię tę opisali najpierw w Dużym Formacie, a następnie w książce Zatoka świń Bożena Aksamit i Piotr Głuchowski (2016). O dużej roli literatury faktu w kontekście charakterystyki Pokolenia Nikt pisał także Leszczyński (2010, s. 39). 


\section{Książka - remedium na cierpienie}

„Jak więc wydobyć się z tego labiryntu cierpienia?” (Green, 2005/2007, s. 189). Pomocą może być właśnie książka ${ }^{11}$, będąca formą „psychicznego wsparcia” (Borecka, 2001, s. 14), którego młody człowiek z różnych powodów nie otrzymuje od najbliższych, przyjaciół, nauczycieli czy rodziców, bądź też które odrzuca. Lektura może stać się rodzajem autoterapii - sprawić, że czytelnik poszukujący pomocy odnajdzie wyjście z trudnej sytuacji (s. 17) ${ }^{12}$ dzięki utożsamieniu się z bohaterem i doświadczeniu swego rodzaju katharsis, czyli „takiego stanu psychicznego, w trakcie czytania lub po jego zakończeniu, który charakteryzuje się odczuciem ulgi, odreagowaniem psychicznych napięć i blokad" (s. 43). Celem niniejszego artykułu jest przeprowadzenie biblioterapeutycznej analizy powieści Jak ziarnka piasku w oparciu o założenia teoretyczne zaprezentowane przez Irenę Borecką (2001), jedną z czołowych przedstawicielek biblioterapii, która w swym poradniku przedstawia m.in. modele postępowania biblioterapeutycznego, oraz Danutę Gostyńską (1979, s. 63-70), która - podobnie zresztą jak pierwsza badaczka wskazuje na dwupoziomowość lektury o działaniu biblioterapeutycznym.

Pierwsza z badaczek zwraca szczególną uwagę na rolę i pośrednictwo biblioterapeuty, który w „konkretny sposób wspomaga pacjenta lub wychowanka" w procesie postępowania terapeutycznego (Borecka, 2001, s. 42). Autorka wskazuje również na „stałe elementy działań terapeuty i uczestnika biblioterapii":

a) czytanie, stuchanie lub ogladanie odpowiednio dobranych środków terapeutycznych (książki, fragmenty utworów, alternatywne materiały czytelnicze oraz teatralne lub filmowe adaptacje utworów literackich),

b) identyfikacja $\mathrm{z}$ bohaterami literackimi lub z sytuacją fikcyjną,

c) przeżycia doznawane podczas kontaktu z zaleconym dziełem (pozytywne lub negatywne) mające na celu uaktywnienie lub emocjonalne wyciszenie uczestnika biblioterapii,

d) katharsis - doznanie takiego stanu psychicznego, w trakcie czytania lub po jego zakończeniu, który charakteryzuje się uczuciem ulgi, odreagowaniem psychicznych napięć i blokad,

e) wglad w siebie samego; przepracowanie, samodzielnie lub przy pomocy biblioterapeuty ważnych osobistych problemów czytającego,

11 Z zastrzeżeniem do moich poprzednich rozważań - musi być to lektura niosąca czytelne rozwiązania, pomoc, niepozostawiająca czytelnika bez odpowiedzi.

12 Biblioterapia jest w swoich celach zbliżona do psychoterapii. Jednym z jej założeń jest „pomoc w odnalezieniu się w nowej, trudnej sytuacji” (Borecka, 2001, s. 17). 
f) zmiany w postawach lub zachowaniu uczestnika procesu,

g) ewaluacja [wyróżnienia oryginalne] (s. 42-43).

Sądzę, że powyższe działania można zastosować (z pomocą biblioterapeuty, który zaproponuje odpowiedni model postępowania biblioterapeutycznego, bądź nauczyciela, pedagoga, bibliotekarza o odpowiednich, biblioterapeutycznych kwalifikacjach) przy odczytaniu powieści Jak ziarnka piasku. Borecka wspomina także o „interdyscyplinarnym charakterze biblioterapii”, podkreślając jej przenikanie się z innymi rodzajami działań terapeutycznych (np. muzykoterapii, arteterapii, sylwoterapii; s. 16) - jest to założenie niezwykle istotne w kontekście problematyki tego artykułu, gdyż w dalszej części tekstu będę odwoływać się również do arteterapii.

Druga z badaczek, Gostyńska (1979; cyt. za: Matys, 2001, s. 6-10), wskazuje na dwupoziomowość lektury o działaniu biblioterapeutycznym. Z jednej strony, lektura „leczy” - pozwala czytelnikowi odnaleźć równowagę psychiczną, pobudza go do konkretnych działań, jest pomocą w rozwiązywaniu życiowych problemów; z drugiej zaś strony:

[...] na poziomie drugim, długofalowym, zadanie terapii czytelniczej polega na porządkowaniu życia wewnętrznego człowieka i wypracowaniu właściwej postawy moralnej w obliczu [...] czy to cierpienia, czy trudności, które towarzyszą w życiu. Ma pomóc [...] [w odnalezieniu], na miarę możliwości intelektualnych i charakterologicznych, społecznie dodatniego celu życia [wyróżnienie własne] (s. 7).

Sądzę, że powieść Jagiełło może nieść pocieszenie młodej osobie, która doświadczyła śmierci kogoś bliskiego, w szczególności - przyjaciela, a także ma potencjał, by stać się pomocą dla nastolatka borykającego się z wieloma innymi problemami wieku dorastania. Na przykładzie głównej bohaterki powieści pisarka pokazuje terapeutyczne sposoby odnalezienia się w kryzysowej sytuacji, które zaprezentuję w dalszej części tekstu. Artykuł podzieliłam na trzy części, odpowiadające etapom, przez które przechodzi główna bohaterka, Anna. Są to kolejno: 1. zagubienie, niemoc, niechęć do działania, próba ucieczki od problemów, 2. punkt kulminacyjny - zmierzenie się z problemami i słabościami, 3 . wyzwolenie ${ }^{13}$.

13 Przyjęty w artykule podział ma na celu, jak wcześniej podkreślałam, ukazanie procesualności zmagania się z problemami (od trudności po wyzwolenie), związanymi w szczególności z nagłą śmiercią bliskiej osoby, a zaprezentowane terapeutyczne rozwiązania należy rozpatrywać w charakterze indywidualnym. 


\title{
W głąb labiryntu. Zagubienie
}

\author{
Przede mna droga w miasto utrapienia, \\ Przeze mnie droga $w$ wiekuiste męki, \\ Przeze mnie droga w naród zatracenia [...]. \\ Ty, który wchodzisz, żegnaj się z nadzieja...
}

- Dante Alighieri, Boska komedia, 1-3, $9^{14}$

Wiadomość o tragicznej śmierci przyjaciółki dociera do Anny nagle, w najmniej spodziewanym momencie: gdy bohaterka radośnie bawi się podczas zimowego wyjazdu, Nina podejmuje decyzję, która - jak się okaże - na długo pozostanie bolesnym wspomnieniem. Anna nie potrafi pogodzić się z wyborem przyjaciółki ani ze świadomością, że nigdy już z nią nie porozmawia. Przecież obie były:

Jak dwie krople wody. Jak dwa groszki, dwie fasolki, dwie bliźniaczki, papużki, koła tego samego roweru, liście z tego samego drzewa, jak pan i pies, jak z krwi krew [...]. Jak dwie krople wody. Dwa ziarnka piasku (Jagiełło, 2018, s. 13).

Narratorka i jednocześnie protagonistka utworu powraca do wspólnych wspomnień, łączących ją z Niną, a także do związanych z nimi miejsc - próbuje w ten sposób odnaleźć ukochaną osobę ${ }^{15}$, ale z bólem zdaje sobie sprawę, że jej już tam nie ma, co obrazują poniższe fragmenty tekstu:

Zaczyna się ściemniać. Lampy na molo przypominają płonące zapałki, a karłowate drzewa człowieczeją. Boję się ich, mam wrażenie, że zaraz w ciemności te konary porwą mnie gdzieś jak Dorotkę do Krainy Oz. Może tak byłoby lepiej, bo nie chcę tu być. Na razie tworzę własną rzeczywistość. Bezpieczny świat to trasa, którą należy pokonać. To mijanie tych samych budynków, ulubionych miejsc na plaży [...]. Teraz Nino, przede wszystkim mi ciebie brakuje. Już nawet nie jestem zła. Morze wypłakało tę złość, wiatr ją wywiał, tyle płakał za tobą, że i ja zaczęłam. Płakać, zamiast się wściekać (s. 17).

14 Powyższy cytat z Boskiej komedii (podany w przekładzie Edwarda Porębowicza; Alighieri, 1472/1965, 1-3, 9) został również wykorzystany jako motto jednego z rozdziałów Buntu czytelników (Leszczyński, 2010, s. 40).

15 Podążanie szlakiem miejsc, łączących bohatera z ukochaną osobą, przypomina fabułę powieści 13 powodów Jaya Ashera (2007/2017). Po samobójczej śmierci przyjaciółki, Hannah, główny bohater powieści, Clay, odsłuchuje pozostawione przez nią nagrania na kasetach. Wyrusza do przywołanych przez przyjaciółkę miejsc, by odkryć, co sprawiło, że podjęła tę tragiczną decyzję. 
Trudno było wchodzić do twojego bloku. Wszystko mi się tam kojarzy z tobą. Człowiek nie myśli o tym na co dzień, dopiero kiedy coś się stanie. Nie zastanawiamy się, jak bardzo ludzie związani są z pewnymi miejscami. I kiedy ich zabraknie, te miejsca też cierpią. Schody wydają się cierpieć, Nino! Nigdy nie zapomnę, jak po nich zjeżdżałyśmy na flanelowych kocach. Nienormalne! Boże, jak to uwielbiałyśmy! Są wyślizgane, także przez ciebie. Jest znak, pamięć (s. 44).

Po czasie Anna wyznaje koleżankom Niny:

- Wiecie co jest najgorsze? - mówię - Wcale nie pierwszy szok. Bo w szoku człowiek zachowuje się irracjonalnie, trochę jak szalony, krzyczy, płacze, a ja chodziłam na spacery godzinami...

- Godzinami?

- Tak, wagarowałam. Potrafiłam tak chodzić po dziesięć godzin. I wydaje ci się wtedy, że to jest najgorsze, co może cię spotkać, ale wcale nie. Najgorszy jest czas, po który rozpościera się od tego momentu aż do zawsze (s. 87-88).

Początkowo bohaterka naiwnie myśli, że uda jej się cofnąć czas, że odtwarzanie wspólnych wspomnień i miejsc przywróci do życia nieżyjącą przyjaciółkę, ale tak się nie dzieje. Anna błądzi w labiryncie wspomnień. Wszystkie miejsca zdają się krzyczeć, że Niny już nie ma ${ }^{16}$. Znane zakątki nagle stają się obce i opustoszałe, wręcz przerażające. Te budynki, plaże, morze, drzewa - też zdają się cierpieć, współodczuwać z bohaterką ból wynikający ze straty ${ }^{17}$. Anna sądzi, że podążanie przyjacielskimi szlakami będzie jak swoista terapia, która przyniesie jej spokój i ukojenie w cierpieniu - dlatego odbywa wielogodzinne spacery po śladach przyjaciółki. Jednak zamiast ukochanych miejsc tętniących życiem zastaje miejsca umarłe, „zatrute”, „zainfekowane śmiercią" (Jagiełło, 2018, s. 32). Zamiast cieszyć się ich widokiem, dziewczyna smuci się, zamiast kontemplować naturę w ciszy - chce krzyczeć i płakać. Jagiełło pokazuje całą skalę emocji, których doświadcza główna bohaterka po stracie ukochanej osoby ${ }^{18}$.

${ }^{16}$ W nocie jurorskiej książki, opublikowanej na stronie Polskiej Sekcji IBBY, Irena Bolek ([2018]) przyrównała część pierwszą powieści do trenu - Anna rozpacza po stracie ukochanej osoby i wspomina minione lata spędzone z przyjaciółką, a te wspomnienia przeplatają się z teraźniejszością. Jagiełło zastosowała też ciekawy zabieg - nagłówki „rozdziałów” w części pierwszej informują o wieku Anny i Niny w danym momencie opowieści.

17 Podobnie jak np. w romantycznej czy młodopolskiej psychizacji krajobrazu, gdzie natura oddawała uczucia bohatera.

18 Czytelnik, identyfikując się z bohaterką, również może współodczuwać i uzewnętrzniać emocje w trakcie lektury - zarówno te pozytywne, jak i negatywne. Te przeżycia mają na 
Za inną próbę podjęcia terapii można uznać sposób, w jaki nastolatka „rozmawia” ze zmarłą przyjaciółką - przemawia do niej tak, jakby Nina wciąż była obecna blisko niej („A ty jesteś teraz szczęśliwa? Naprawdę ci lepiej? Nie rozumiem, dlaczego to zrobiłaś [...]. Nie pomyślałaś, jak to na mnie wpłynie?" - Jagiełło, 2018, s. 20; „A teraz... teraz nie chcę, żeby ciebie nie było, Nino” s. 21; „Nie no, Nino nie oburzaj się. Wiem, jak było u ciebie” - s. 36). Ten sposób wypowiedzi przypomina list albo konfesyjny pamiętnik. Znaczące jest to, że narratorka wciąż zwraca się bezpośrednio do przyjaciółki, nieustannie przywołuje jej imię. Zadaje też mnóstwo pytań, które pozostają bez odpowiedzi. Nina milczy, co sprawia, że Anna odczuwa jeszcze większą pustkę i samotność. Rozmowa, choć przypomina modlitwę, w żaden sposób bohaterki nie umacnia, powoduje jeszcze większe zagubienie - ten rodzaj terapii również się nie sprawdza.

Ból jest tym dotkliwszy, że to nie pierwsza śmierć kogoś bliskiego w życiu nastolatki - pierwszą kochaną przez Annę osobą, która odeszła przedwcześnie, był jej ojciec ${ }^{19}$. Obok Niny to on odgrywał ważną w jej życiu rolę, gdyż dziewczyna nie miała prawie żadnych relacji z matką. Mimo wad ${ }^{20}$ zawsze był wobec niej kochającym rodzicem - zabierał ją na wycieczki z przyjaciółką, żartował, wnosił do domu radość. Z matką dziewczyna nie może się porozumieć, nie ufa jej, tym bardziej, że ma wrażenie, że ta nie kochała jej ojca. Kobieta nie potrafi zrozumieć też problemów córki, Anna nie znajduje więc w niej oparcia, co obrazuje np. poniższy fragment dialogu obu bohaterek:

- Przestań - ucinam. - Nie chcę znowu słyszeć: „Twoja przyjaciółka zrobiła coś głupiego".

- Powiem jeszcze raz: „Twoja przyjaciółka zrobiła głupstwo”. Nikt nie ma prawa odbierać sobie życia z jakiegoś błahego powodu...

- Przecież nie wiemy, z jakiego powodu to zrobiła!

celu „uaktywnienie lub emocjonalne wyciszenie uczestnika biblioterapii”; jest to etap poprzedzający katharsis (Borecka, 2011, s. 43).

19 Protagonistka, niczym bohater bajki ludowej, przechodzi trzy inicjacyjne próby prowadzące do czwartej, finałowej - te próby to w przypadku Anny kolejno śmierć ojca, następnie - przyjaciółki, w końcu - ukochanego psa. Ostatnią próbą jest bliskie otarcie się o śmierć samej bohaterki (o tym piszę w dalszej części artykułu).

${ }^{20}$ Między wierszami czytelnik dowiaduje się o nadużywaniu alkoholu przez ojca bohaterki (jednak jest to relacja z perspektywy dziecka, oparta na wspomnieniach Anny, więc odbiorca nie wie, czy mężczyzna był alkoholikiem, czy też były to sporadyczne sytuacje) oraz o nieufności jej matki wobec męża - m.in. przez to, że nie potrafił znaleźć stałej i pewnej pracy. 
- Daj mi skończyć. Codziennie stykam się z ludźmi, którzy mają prawdziwe problemy.

Jasne. Jej seniorzy z domu kultury mają prawdziwe problemy. Są starzy i chorzy, ledwo chodzą i ciągle ich coś boli. A mimo to starają się jeszcze coś zrobić ze swoim życiem. Słyszałam to już z milion razy. [...]

Moja matka uważa, że za bardzo to przeżywam. Denerwuje ją mój smutek. Jest pozbawiona emocji, przypomina unoszącą się na falach meduzę, której wszystko jedno. Tak samo było, kiedy umarł ojciec. „Bóg tak chciał”. Jaki Bóg?! Żaden normalny człowiek nie może chyba wierzyć, że Bóg istnieje, patrząc na to, co dzieje się na świecie [...] o Bogu nie da się z matką rozmawiać, tak samo jak o tym, że ojciec umarł na własne życzenie. „Nagrabił sobie” - mówi matka grobowym głosem, z pewną satysfakcją. A ja, kiedy tego słucham, nie wiem, jak on z nią wytrzymywał (Jagiełło, 2018, s. 33-34) ${ }^{21}$.

W zacytowanym dialogu i przykładach z nim korespondujących znajdują potwierdzenie przywoływane przeze mnie wcześniej refleksje, że Pokolenie Nikt w zasadzie nie ma żadnych autorytetów, jak rodzina, Bóg - straciły one bowiem rację bytu; młody człowiek nie znajduje w reprezentowanych przez nie wartościach żadnego oparcia. Matka traci w oczach Anny autorytet, gdy bagatelizuje utratę ojca i śmierć Niny - córka zwraca się zresztą do matki w rozkazujący, bezpośredni sposób, jak do koleżanki lub obcej osoby (co obrazuje już pierwsze zdanie powyższej rozmowy). Czytelnik zna co prawda tylko perspektywę Anny i początkowo ufa bardziej narratorce niż jej matce ${ }^{22}$, jednak już sam

21 Przywołany dialog jest jednym z wielu przykładów ukazujących niemożność porozumienia się matki i córki; takich egzemplifikacji można odnaleźć w powieści więcej (np. dialog Anny z matką po śmierci ich psa, Ariego; Jagiełło, 2018, s. 177-178), por. również przykładowe przemyślenia Anny na temat jej relacji z rodzicem: „I znowu myślę o tym, jak jesteśmy różne [...]. [Matka] [n]ikomu nie daje taryfy ulgowej, nad nikim się nie roztkliwia [...]. Bo ona jest sztywna, jakby kij połknęła. Pewnie dlatego zupełnie nie możemy się do siebie zbliżyć. Czuję się tak, jak gdyby dzieliły nas lata świetlne... Jest niby wykształcona, a niektóre poglądy ma strasznie zaściankowe” (s. 157-158); „Mnie też tak kocha - nie kocha. To znaczy nic jej w sumie nie można zarzucić. Pewnie nawet stara się być sprawiedliwa, przynajmniej zgodnie ze swoim poczuciem sprawiedliwości. W życiu nie zrobiła mi nic złego. Tylko mam wrażenie, że ciągle ją zawodzę, choć trudno stwierdzić dlaczego. Tak po prostu. Zawodzę, bo jestem zbyt emocjonalna. Zawodzę, bo za dużo chcę. Zawodzę, bo się nad sobą roztkliwiam. W dodatku ona nic nie mówi, muszę to wszystko odczytywać między wierszami. Że jest rozczarowana, bo nigdy nie będę taka jak ona” (s. 158). Anna nie potrafi rozmawiać z matką o swoich uczuciach, ale początkowo nie chce też jej bliżej poznać - jednoznacznie ocenia rodzica jako osobę oschłą, surową. Ta relacja zmienia się znacząco pod koniec powieści, tak jak zmieniają się obie bohaterki.

22 Ten zabieg pozwala zresztą nastoletniemu czytelnikowi odczuwać problemy razem z bohaterką, odnaleźć bliską mu sytuację w tych dotyczących postaci i doświadczyć swoistego 
dialog ukazuje niemożność porozumienia, wczucia się w rolę drugiej osoby, a przy tym ów odbiorca odkrywa tragedię i matki, niepotrafiącej rozmawiać o uczuciach z dzieckiem, i nastoletniej córki, dla której kolejna śmierć bliskiej osoby staje się uciążliwą traumą. Rozmowa z bliskim jako próba terapeutycznej pomocy także kończy się więc w przypadku Anny fiaskiem.

Zdaje się, że bohaterka parafrazuje wcześniej przywoływane już pytanie „Jak wydobyć się z [...] labiryntu cierpienia?”, gdy „rozmawia” z nieżyjącą już Niną:

Co prawda, mam poczucie, że mnie też powoli zabija, Nino, ten ciągły ciebie brak, te wszystkie odniesienia, skojarzenia, porównania. Jak żyć w tym mieście, które wciąż - dla mnie - pulsuje tobą? Pójdę tam, w to miejsce, pożegnam się z tobą. Błagam, spraw, żebym jakoś znormalniała. Jeśli potrafisz, spraw, bym, choć trochę przestała o tobie myśleć. Wiem, że to okropna prośba. Jak mogę cię prosić, abyś pomogła mi przestać o tobie myśleć? A jednak proszę, błagam, dłużej tego nie wytrzymam. Wiesz, że zawsze byłam słaba, i wiesz, jak bardzo przeżyłam śmierć ojca. Teraz mam wrażenie, że to już za dużo. Rozpadam się na kawałki jak wtedy te białe kafelki w Macu rozpadły mi się w głowie, jak te potłuczone szyby na wystawie, rozpadam się na fragmenty razem z tobą. Czy po czymś takim można jeszcze żyć normalnie? (Jagiełło, 2018, s. 71-72).

\section{W głąb króliczej nory. Przełom}

Czułam się trochę jak Alicja w tej swojej Krainie Czarów, tylko nie wiedziałam, w co wpadnę. A teraz już wiem, że to po prostu ciemność. Nic. Pustka, brak wszystkiego i w końcu - brak ciebie (Jagiełło, 2018, s. 27).

Anna coraz silniej przeżywa śmierć przyjaciółki, co zaczyna odbijać się na jej zdrowiu zarówno fizycznym, jak i psychicznym ${ }^{23}$ - nadal ucieka też w miejsca znane tylko sobie i Ninie. To ucieczka od otaczającej ją rzeczywistości. Gdy

\footnotetext{
katharsis - o czym pisałam wyżej, powołując się na tezy Boreckiej (2001, s. 43). Warto jednak zaznaczyć, że w ujęciu teorii fokalizacji Gérarda Genette’a (1972/1980) perspektywa Anny jest narracją z wewnętrzną, stałą fokalizacją - czytelnik ma wgląd wyłącznie w myśli głównej bohaterki, nie może więc jej uznać za wszechwiedzącego i w pełni wiarygodnego narratora.

23 Istotnym zagadnieniem $\mathrm{w}$ kontekście analizy tych fragmentów powieści są rozpoznania psychiatryczne i psychologiczne, jednak wykraczają one poza przyjętą perspektywę artykułu. Szersze refleksje ten temat przedstawili m.in. - w formie poradnikowo-komiksowej - Katarzyna Szaulińska i Daniel Chmielewski (2016) oraz - w formie poradnika - Konrad Ambroziak, Artur Kołakowski i Klaudia Siwek (2018).
} 
udaje się na wystawę sztuki współczesnej, dostrzega przerażające postacie, obserwujące ją oczy, maski, półtwarze, rozpadające się elementy, ciała w agonii (s. 71). Czy to sen czy jawa? Bohaterka już sama nie jest w stanie tego stwierdzić, śmierć Niny coraz silniej na nią oddziałuje. Prosi kolegę, by pokazał jej miejsce, gdzie ukochana przyjaciółka odebrała sobie życie. Tam, w mrocznym lesie, najmocniej powraca obraz samobójczej śmierci bliskiej osoby. Dla Anny jest to już jednak zbyt wiele:

Nie chcę niczego więcej, tylko wracać i nigdy już tu nie przychodzić. Nino, uwolnij mnie od siebie, ja naprawdę tego nie zniosę. Wszystko mi lata przed oczami: obrazy w galerii, konar, sznur, twoja twarz, obrazy... Pierroty. Znowu prawie osuwam się w pustkę, ale Łukasz mnie podtrzymuje, daje mi wody, mówi mi, że już niedaleko, że zaraz będziemy przy samochodzie. Jakoś udaje mi się dojść. Przy samym aucie jeszcze rzygam w śnieg, choć właściwie nie mam czym, naprawdę ostatnio prawie nic nie jem. Łukasz podaje mi chustki, wyciera, wyrzuca, wsadza mnie do auta. Daję radę wyszeptać „dziękuję" i znowu zapadam w ciemność (s. 74).

Dziewczyna, podobnie jak Alicja z powieści Lewisa Carrolla (1865), czuje, że spada w metaforyczną Krainę Śmierci (Czernow, 2018, s. $107-114)^{24}$. Powracające wspomnienia wirują wokół niej. Tak jak literacka bohaterka spotyka się z niezrozumieniem ze strony otaczających ją osób, a czasem kpiną, wyśmianiem (wystarczy przytoczyć np. wyżej przywołany dialog z matką). Sny mieszają jej się z rzeczywistością, przywołują obrazy zmarłej przyjaciółki - fascynują ją, ale i przerażają (Jagiełło, 2018, s. 24). Te dwa światy przenikają się $e^{25}$ - fantazyjny świat wspomnień związanych z Niną i świat rzeczywisty. Anna musi odpowiedzieć sobie na pytanie, stawiane również przez bohaterkę wkraczającą do Krainy Czarów, kim w zasadzie jest. Nastolatka początkowo bezskutecznie próbuje wejść w różne role ${ }^{26}$ : córki, dziewczyny, uczennicy, przyjaciółki. Z matką, jak wspominałam, nie potrafi się porozumieć. Gdy przeżywa pierwszą miłość, chwilowo zapomina o śmierci Niny, ale zaraz potem doświadcza bolesnego odrzucenia. Jako uczennica - nie potrafi sprostać wymaganiom

${ }^{24}$ Jak podaje Anna Maria Czernow (2019), sen - który stanowi zresztą główną ramę dylogii o Alicji - już w starożytności interpretowano jako metaforę śmierci. Badaczka zwraca także uwagę na nazwę krainy, do której trafia Alicja, podaną w pierwotnej wersji - Under Ground [pod ziemią], co przywołuje skojarzenia z zaświatami, mitycznym królestwem Hadesu (s. 108-109).

25 Zupełnie jak w baśni, gdzie dwa światy - realny i fantastyczny - nieustannie się przenikają, choć nie ulega wątpliwości, że zabieg ma tu inną funkcję.

26 Ponownie niczym Alicja w utworze Carrolla. 
nauczycielki, a jako koleżanka - wciąż ma wyrzuty sumienia, że w żaden sposób Ninie nie pomogła, że nie wsparła jej w trudnej sytuacji. Kryzys dodatkowo pogłębia nieustanne porównywanie się Anny do przyjaciółki - to Nina była tą „lepszą”, tzn. zdolniejszą, piękniejszą ${ }^{27}$. To działanie jest czysto destrukcyjne - Anna uważa się za nic nieznaczącą „Pannę Nikt”.

Przełom następuje, gdy dziewczyna decyduje się zająć miejsce koleżanki i prosi o ponowne przyjęcie do liceum plastycznego, do którego obie składały dokumenty (Anna nie dostała się jednak do wymarzonej szkoły, była na pierwszym miejscu listy rezerwowej). Teraz, gdy po Ninie zwolniło się miejsce, nastolatka odważnie podejmuje próbę „wejścia w jej buty” (Jagiełło, 2018, s. 104) ${ }^{28}$. Ten krok uświadamia jej, jak różnymi „ziarnkami piasku” były przyjaciółki oraz jak bardzo ich drogi się rozeszły. Dziewczyna przekonuje się, że przyjaźń z Niną, choć bardzo dla niej znacząca, paradoksalnie zamknęła ją na wszelkie inne przyjacielskie kontakty ${ }^{29}$. Zaczyna rozumieć, że porzuciła malowanie tylko dlatego, że uważała, że z nich dwóch jedynie Nina miała prawdziwy talent. Dostrzega także, że za każdym razem, kiedy nie potrafiła się porozumieć z rodzicem, sama była temu winna, bo porównywała swoją matkę z matką przyjaciółki ${ }^{30}$. Gdy poznaje szkolnych znajomych Niny, odkrywa również zupełnie inny obraz koleżanki (cichej, wycofanej, nieśmiałej, zamkniętej we własnym,

27 Przykładowe fragmenty: „[...] są ładni i ładniejsi (ja byłam taka sobie, ty - ładniejsza)” (Jagiełło, 2018, s. 22); „Na pewno zadaje sobie pytanie [matka Niny], czemu to ty, a nie ja? W końcu zawsze byłaś tą zdolniejszą, tą, której wszystko się udaje. No cóż, nie zapyta mnie o to, a ja miałabym ochotę powiedzieć, że to też ci się udało. Bo ja na twoim miejscu pewnie bym spieprzyła sprawę. To ty dostałaś się do plastyka, ty wygrywałaś konkursy, więc konkurs na najładniejszą śmierć samobójczą też musiałaś wygrać” (s. 43); „Moje rysunki niestety są nieporadne, choć bardzo lubię plastykę. Wiem, że jeśli się postaram będę rysowała lepiej, ale czy tak jak Nina?” (s. 50); „Szkoda, że nie nauczyłaś mnie, jak się uczyć Nino. Tobie zawsze przychodziło to łatwo. Po prostu byłaś inteligentniejsza, było to dla mnie oczywiste” (s. 51); „Zamieniam się w ciebie, zawsze byłaś bardziej eteryczna, bardziej uduchowiona. Przyznajmy: zawsze byłaś lepsza" (s. 59).

28 Mimo strachu i niewiary we własne możliwości („A jednak do tamtej szkoły poszłam, wmawiając sobie, że na pewno się nie uda”; Jagiełło, 2018, s. 80) oraz wątpliwości najbliższych, czy wejście na miejsce przyjaciółki aby na pewno jest dobre (s. 104).

29 Ilustrują to słowa narratorki: „To straszne, ale przez chwilę czuję się z tego powodu szczęśliwa, niczym nieograniczona, zupełnie wolna. I nie jest wcale miła myśl, że Nina mnie w jakiś sposób ograniczała. Czy to znaczy, że jeśli mamy w życiu kogoś bliskiego, to on nas zawsze ogranicza?” (Jagiełło, 2018, s. 145).

30 Matka Niny w oczach Anny: „Pracowała dużo, wracała wieczorem, ale starała się spędzać czas z córką. Nina chodziła z mamą na wystawy, do restauracji i na zakupy. Dla mnie to był obcy świat, bo ja z mamą nie chodziłam nigdzie" (Jagiełło, 2018, s. 67). 
artystycznym świecie), zupełnie nieprzystający do jej własnych wyobrażeń żywiołowej, towarzyskiej i śmiałej osoby.

Pozornie idealna Nina również miała problemy, i ona błądziła w labiryncie cierpienia. Anna przekonuje się o tym, gdy podąża tą samą ścieżką, poznaje nauczycieli przyjaciółki i w końcu doświadcza tego samego - zakochuje się w nauczycielu, który uwodzi ją wizją galerii sztuki i wraz z innymi mężczyznami szantażuje i wykorzystuje seksualnie. W przeciwieństwie do Niny postanawia jednak walczyćc $^{31}$ - ucieka z miejsca zbrodni i porywa ze sobą dowody: nagrania filmów, na których ukazano akty przemocy seksualnej dokonane na niej, Ninie i wielu innych dziewczynach. Choć wciąż się boi i nie chce tej sytuacji nigdzie zgłaszać, ma odwagę podzielić się nią z przyjacielem, Łukaszem. To on ją ratuje, gdy sama prawie ociera się o śmierć (i jest gotowa popełnić samobójstwo), namawia też dziewczynę do podzielenia się z innymi swoją historią. Ten moment uświadamia Annie, że ma dla kogo żyć i że choć każdy mierzy się z poważnymi problemami, to należy o tych trudnościach głośno mówić i nikogo nie pozostawiać samego.

\section{W głąb sztuki. Wyzwolenie}

Tworzę jak szalona i wszystkie prace chowam pod łózko. Wolałabym nie pokazywać ich mamie, mogłaby pomyśleć, że z moim zdrowiem psychicznym jest coś nie tak, a jest wprost przeciwnie. Z każdym portretem czuję coraz większą ulgę. Zastanawiam się, czy nie tak powstały najwspanialsze dzieła: aby ulżyć ich twórcom w cierpieniu (Jagiełło, 2018, s. 85).

Anna zadaje sobie już nie pytanie, kim jest, a kim się staje, dzięki wsparciu bliskich i odzyskaniu poczucia własnej wartości. Odkrywa przy tym, że jej matka również była bardzo samotna i potrzebowała miłości, a najbliższy przyjaciel, Łukasz, w tragiczny sposób utracił bliską osobę. Podzielenie się własnymi uczuciami i historiami okazuje się dla dziewczyny pomocą, zachętą, by śmielej mówić o swoich trudnościach i problemach. W oczach innych Anna nie jest już „Panną Nikt”, jak sama o sobie kiedyś myślała, staje się „bohaterką” (s. 269, 271), której udało się zwycięsko wyjść z trudnej sytuacji ${ }^{32}$.

31 Można mówić tu o podjęciu metaforycznej „gry w śmierć”, nawiązując do tytułu przywołanej już powieści Casty. Bohaterka istotnie toczy grę ze śmiercią, walczy, by nie oddać się w jej ręce, by jak Nina nie podjąć tragicznej decyzji. O wiecznej „grze w śmierć” pisał także David Kessler (1997/1999).

32 Symboliczne odrodzenie bohaterki ponownie pokazuje łączność jej uczuć oraz emocji z naturą - akcję powieści rozpoczynała zima, kończy ją pora roku zwiastująca nowe życie, wiosna. 
Poza wsparciem bliskich dużą rolę odegrała w życiu protagonistki sztuka. To przede wszystkim ona umożliwiła Annie oswojenie się z problemami i zminimalizowanie cierpienia, gdy nastolatka nie potrafiła poprosić nikogo o po$\operatorname{moc}^{33}$. Tworzenie obrazów pozwoliło jej przelać na płótno wszelkie emocje, z którymi się zmagała, było wyzwoleniem - o czym mówi choćby przytoczony na początku podrozdziału cytat, powtórzmy: „Z każdym portretem czuję coraz większą ulgę. Zastanawiam się, czy nie tak powstały najwspanialsze dzieła: aby ulżyć ich twórcom w cierpieniu" (Jagiełło, 2018, s. 85). Przywoływani przez nastolatkę ulubieni artyści mogli być dla niej zresztą autorytetem, wzorem, inspiracją - osoby takie jak Frida Kahlo czy Vincent van Gogh również zmagały się ze słabościami, a sztuka była dla nich ostoją, ucieczką od bólu, przynosiła im ulgę w cierpieniu (s. 85).

Można tu wręcz mówić o swoistej arteterapii (Konieczna, 2003) ${ }^{34}$, przejawiającej się w przelewaniu na papier aktualnych uczuć. Gdy Anna doświadczała pustki, samotności i kolejny raz - śmierci bliskiej osoby, malowała obrazy. Ukazują to następujące fragmenty powieści:

Kupiłam duże kartony w różnych kolorach i zaczynam malować autoportrety. W tym celu kładę przed sobą lustro. Chciałabym stworzyć coś w rodzaju portretów Fridy. Maluję siebie z lewej strony, dookoła kwiaty, liście i owoce. Oczywiście

33 Innym terapeutycznym rozwiązaniem ukazanym w powieści jest pewnego rodzaju dogoterapia. Napotkany na obozie harcerskim pies staje się dla Anny bliskim przyjacielem i pozwala (przynajmniej chwilowo) oswoić się z sytuacją śmierci przyjaciółki, a także - z szerzej pojętym tematem śmierci. Przygarnięty przez bohaterkę Ari dość szybko umiera (ten moment, jak wcześniej wspominałam, jest jedną z inicjacyjnych prób, przez które musi przejść nastolatka). Pod koniec powieści Anna, wspólnie z mamą, decydują się na adopcję nowego psa. Bohaterka zaczyna też pracować jako wolontariuszka w schronisku.

34 Posługuję się terminem „arteterapia” rozumianym w wąskim znaczeniu jako „terapia z użyciem sztuk plastycznych”, nosząca również nazwę „plastykoterapii” lub „terapii malarskiej”, o czym pisze Ewelina J. Konieczna (2003, s. 18). Badaczka wymienia również funkcje arteterapii i podaje, że: „Obok funkcji pragmatycznej, służącej do zapewnienia jednostce podstawowych potrzeb, arteterapia ma istotne znaczenie w procesie komunikacji interpersonalnej, ułatwia bowiem wyrażanie intrapsychicznych konfliktów w sposób pozawerbalny. Jej funkcja kompensacyjna ma na celu zaspokajanie niezrealizowanych potrzeb jednostki, a poznawcza uczy nazywania, wyrażania i rozpoznania uczuć. Arteterapia posiada też walory relaksacyjne, odprężające i stymulujące, ponieważ rozbudza korzystne emocje i pozytywnie wpływa na samopoczucie. Funkcja regulacyjna umożliwia zaspokojenie potrzeb samorealizacji oraz kompensuje braki i niepowodzenia doznawane w określonej dziedzinie życia [wyróżnienia własne]" (s. 27). Pogrubione fragmenty cytatu wydają mi się najbardziej znaczące w kontekście bohaterki powieści Jagiełło. Temat arteterapii poruszała również szerzej Wita Szulc (2011). 
przypominam siebie tylko trochę, najbardziej chyba z włosów. Nadal nie nauczyłam się dobrze oddawać twarzy. Poza tym czegoś mi na portrecie brakuje. Po drugiej stronie powstaje postać. Kredka wydaje się sama rysować, nie myślę wiele o tym, co robię, to pewnie przez tę symetryczność portretów Kahlo, ale oczywiście to Ninę maluję po drugiej stronie. Moją siostrę bliźniaczkę w otoczeniu nietoperzy i węży. Straszny to rysunek: ja taka promienna i wiosenna, ona mroczna. Ale, nie wiedzieć czemu przynosi mi to ulgę [wyróżnienie własne] ${ }^{35}$.

Przez pierwszy miesiąc wakacji maluję niezliczone portrety swoje i Niny. Zawsze jesteśmy przedstawiane jako dwa lustrzane odbicia i różnimy się otoczeniem. Piasek i ziemia. Gałęzie i niebo. Mewy i kruki. Chmury i woda (Jagiełło, 2018, s. 84-85).

Oczywiście zamiast rysować znienawidzoną martwą naturę (dzbanek, jabłko, szmata), szkicuję siebie jako kościotrupa, czyli śmierć. A obok twarz Niny, ojca i martwego psa. Jezu, mnie samą ten rysunek tak głęboko przeraża, że natychmiast chowam go głęboko do szuflady. Gdyby ktoś się przyjrzał niektórym moim pracom, chybaby mnie zabrał do psychiatryka (s. 154).

Sztuka ma funkcję katarktyczną, a kontakt z nią, o czym już wspomniałam, pozwala zmierzyć się ze słabościami. Rolą sztuki jest, jak pisał Zygmunt Bauman, którego poglądy referuje Leszczyński (2010, s. 81), pokonanie:

[...] grozy niekontrolowanego. [Sztuka] pozwala zrozumieć siebie, a bez zrozumienia siebie nie można zrozumieć innego. „Rozumienie - pisze Bauman [(2006/2008, s. 165)] - polega na zdolności radzenia sobie z sytuacją. Nie jesteśmy w stanie poradzić sobie z tym, co jest nam »nieznane«; to zaś, co »nieznane«, przeraża”.

Sztuka pozwala pokonać ten strach, nazwać emocje niemożliwe do opisania. Potrafi również odmienić człowieka. Wreszcie - przyświeca też wyższym celom, nie jest wyłącznie „sztuką dla sztuki” - może pomóc innym. Dostrzega to sama bohaterka, która wykorzystuje swój malarski talent do celów charytatywnych $^{36}$, a także jej matka, która pracuje jako terapeutka, pomagając osobom starszym i z niepełnosprawnościami (Jagiełło, 2018, s. 268-269).

35 W tym kontekście można przywołać autoportrety Fridy Kahlo w otoczeniu natury, a także obraz Dwie Fridy z 1939 roku (przyp. autorki artykułu - Natalii Morawskiej).

36 Tworzy koszulki-manifesty, zwracające uwagę na problem przemocy seksualnej, część zarobionych pieniędzy przeznacza na fundację walczącą z przemocą, a także maluje z Łukaszem portrety psów ze schroniska, mające zachęcić ludzi do adopcji zwierząt. 


\section{Zakończenie. Terapeutyczna moc książki i sztuki}

Pozostaje jednak pytanie, czy sztuka i - przede wszystkim - literatura mogą dziś pomóc współczesnemu nastolatkowi borykającemu się z problemami podobnymi do tych, z którymi zmaga się bohaterka powieści. Czy faktycznie np. książka może być w tym kontekście dobrym medium? Dzisiejsze Pokolenie $\mathrm{Nikt}^{37}$ to przecież generacja, która coraz częściej szuka odpowiedzi na nurtujące ją pytania wcale nie w kręgu rodziny, nauczycieli czy właśnie w książce, a w internecie (często skądinąd stającym się przywołanym „labiryntem cierpienia”). Sądzę jednak, że komunikacja internetowa nie zastąpi w żaden sposób realnego słowa. Lektura natomiast pozwoli młodemu czytelnikowi wyzwolić prawdziwe emocje, sprawi, że nie będzie musiał ukrywać swych uczuć za maską emotikonów. Ewelina J. Konieczna (2003) podkreśla, że to:

[...] nadmierna technicyzacja i dehumanizacja życia sprawiły, że powszechne stało się zjawisko określane mianem „samotnego tłumu”. Oznacza ono wyobcowanie poszczególnych jednostek, wynikające z braku międzyludzkiego porozumienia i lęku przed uzewnętrznianiem uczuć (s. 9).

Dużą rolę odgrywają więc w tym kontekście rodzice, pedagodzy i nauczyciele - to oni są odpowiedzialni za dzisiejsze Pokolenie Nikt (Leszczyński, 2010, s. 60-61, 63) i to oni powinni zachęcać do poszukiwania terapeutycznej pomocy w bliskiej nastoletniemu czytelnikowi lekturze, a także - co pokazuje omawiana przeze mnie powieść - w sztuce. Sama Jagiełło (Krempa, [2020]) podkreślała rolę książki jako pomocy w kryzysowej sytuacji, zwracała przy tym uwagę, że dziecku czasem trudno jest zaufać nawet własnemu rodzicowi (gdy i ten doświadcza problemów bądź krzywdzi dziecko). Lektura może więc stać się dla młodego człowieka terapeutyczną pomocą i wskazać mu przykładowe rozwiązania trudnej sytuacji. Jeszcze inną kwestią jest brak na liście lektur szkolnych książek poruszających - jak powieść Jagiełło - tabuizowane tematy oraz nieobecność w owych lekturach współczesnego bohatera (mającego bliskie dzisiejszemu nastolatkowi problemy), z którym czytelnik mógłby się utożsamić. Jak pisał Leszczyński (2010): „Biblioteka przeznaczona dla nastolatka musi być jego własną biblioteką [...]. To ma być biblioteka dla

37 Postawione w artykule tezy na temat Pokolenia Nikt znajdują potwierdzenie - czy wręcz rozwinięcie - nie tylko w polskich, lecz także w zagranicznych powieściach, takich jak np. 13 powodów Ashera, Notatki samobójcy Michaela Thomasa Forda (2008/2017), Hate list. Nienawiść Jennifer Brown (2009/2011), Fatalna lista Siobhan Vivian (2012/2017), Zanim umre Jenny Downham (2007/2016). 
czytelników, którzy nie gdzie indziej, tylko tu i teraz żyją i zmagają się z własnym losem" (s. 11).

Potrzeba dziś również rozmowy z młodzieżą o takich kwestiach jak śmierć, depresja, wykorzystanie seksualne, przemoc w rodzinie itp. - by nie czynić z nich tematów tabu i mówić o emocjach. Jak pokazuje powieść Jak ziarnka piasku, to milczenie i brak wsparcia najczęściej prowadzą do cierpienia $^{38}$. A jak podkreśla Jagiełło (Krempa, [2020]), „literatura jest trochę jak rozmowa - gdy nie mamy z kim porozmawiać, zawsze pozostają nam bohaterowie literaccy".

\section{Bibliografia}

Aksamit, B., Głuchowski, P. (2016). Zatoka świń. Agora.

Alighieri, D. (1965). Boska komedia (E. Porębowicz, tłum.). PIW. (wyd. oryg. 1472).

Ambroziak, K., Kołakowski, A., Siwek, K. (2018). Nastolatek a depresja. Praktyczny poradnik dla rodziców i młodzieży. Gdańskie Wydawnictwo Psychologiczne.

Asher, J. (2017). 13 powodów (A. Górska, tłum.). Rebis. (wyd. oryg. 2007).

Bauman, Z. (2008). Płynny lęk (J. Margański, tłum.). Wydawnictwo Literackie. (wyd. oryg. 2006).

Bolek, I. ([2018]). Jak ziarnka piasku [nota na temat książki]. IBBY - Polska Sekcja. Pobrane 1 marca $2021 \mathrm{z}$ : http://www.ibby.pl/?page_id=5551.

Borecka, I. (2001). Biblioterapia. Teoria i praktyka. Poradnik. Wydawnictwo SBP.

Borowski, D. (2014). Narkotyczne uczty i ich konsekwencje na podstawie wybranych powieści młodzieżowych. W: J. Bujak-Lechowicz (red.), Kulturowy obraz uczty (s. 21-32). Jasne.

Borowski, D. (2016). Trudna sytuacja jako test dojrzałości (Franciszka Anny Piwkowskiej, Most nad Missisipi Ewy Przybylskiej). W: M. Chrobak, K. Wądolny-Tatar (red.), Światy dzieciństwa. Infantylizacje w literaturze i kulturze (s. 377-391). TAiWPN Universitas.

Brown, J. (2011). Hate list. Nienawiść (M. Mazan, tłum.). Nasza Księgarnia. (wyd. oryg. 2009).

Carroll, L. (1865). Alice's adventures in Wonderland. Macmillan.

38 Jak pisze Leszczyński (2010): „Literatura jest żywą częścią społecznego bytu, rozdrapuje rany, które wrodzony człowieczy oportunizm chciałby zasypać, zamknąć za zasłoną milczenia. Ale milczenie prowadzi do samotności, a ta z kolei do poczucia alienacji, niezrozumienia siebie, blokowania cierpienia, w konsekwencji wzrostu napięcia, do wyniszczenia wewnętrznego, znajdującego ujście w czynach o charakterze destrukcyjnym” (s. 80). 
Cart, M. (2017). Young adult literature: From romance to realism (wyd. 3). American Library Association.

Casta, S. (2007). Gra w śmierć. Książka Kima (B. Gawryluk, tłum.). Zakład Narodowy im. Ossolińskich. (wyd. oryg. 1999).

Czernow, A. M. (2018). „Umrzyj i naródź się na nowo”. W: K. Slany (red.), Śmierć w literaturze dziecięcej i młodzieżowej (s. 107-124). Wydawnictwo SBP.

Downham, J. (2016). Zanim umrę (M. Gajdzińska, tłum.). Nasza Księgarnia. (wyd. oryg. 2007).

Dudzikowska, M., Tomasik, E. (1998). O biblioterapii reminiscencyjnej. Szkoła Specjalna, 4, 279-284.

Fidowicz, A. (2020a). Niepetnosprawność w polskiej literaturze XX i XXI wieku dla dzieci i młodzieży. Wydawnictwo UJ.

Fidowicz, A. (2020b). Polska literatura dziecięca i młodzieżowa w odbiciu crip theory. Wybrane przykłady. Paidia i Literatura, 2, 35-42. https://doi.org/10.31261/ PiL.2020.02.03.

Ford, M. T. (2017). Notatki samobójcy (M. Mazan, tłum.). Nasza Księgarnia. (wyd. oryg. 2008).

Genette, G. (1980). Narrative discourse: An essay in method (J. E. Lewin, tłum.). Cornell University Press. (wyd. oryg. 1972).

Gostyńska, D. (1979). Z problemów biblioterapii. Biuletyn Informacyjno-Instrukcyjny MPB w Krakowie, 120, 63-70.

Green, J. (2013). Gwiazd naszych wina (M. Białoń-Chalecka, tłum.). Bukowy Las. (wyd. oryg. 2012).

Green, J. (2007). Szukajac Alaski (A. Sak, tłum.). Znak. (wyd. oryg. 2005).

Jagiełło, J. (2016). Zielone martensy. Nasza Księgarnia.

Jagiełło, J. (2018). Jak ziarnka piasku. Nasza Księgarnia.

Jagiełło, J. (2020). To już nie ma znaczenia. Zielona Sowa.

Jakubowski, W. (2020). Sex Education, czyli serial jako źródło wiedzy o świecie młodzieży. Studia Edukacyjne, 57, 17-32. https://doi.org/10.14746/se.2020.57.2.

Kessler, D. (1999). Śmierć jest częścia życia. O prawo do godnego umierania (E. Czerwińska, tłum.). Świat Książki. (wyd. oryg. 1997).

Konieczna, E. J. (2003). Arteterapia w teorii i praktyce. Impuls.

Konopnicka, M. (1974). Moi znajomi i inne opowiadania. Czytelnik. (wyd. oryg. 1890).

Korczak, J. (1980). Dziecko salonu. Wydawnictwo Literackie. (wyd. oryg. 1906).

Korczak, J. (2018). Spowiedź motyla. W: J. Korczak, Bobo. Feralny tydzień. Spowiedź motyla (s. 83-171). Rzecznik Praw Dziecka. (wyd. oryg. 1914).

Krempa, S. ([2020]). Literatura jest jak rozmowa. Wywiad z Joanną Jagiełło. Granice.pl. Pobrane 25 stycznia 2021 z: https://www.granice.pl/publicystyka/joanna-jagiello-wywiad/1503/1. 
Leszczyński, G. (2010). Bunt czytelników. Proza inicjacyjna netgeneracji. Wydawnictwo SBP.

Liciński, L. S. (1978). Halucynacje. Z pamiętnika włóczęgi. Wydawnictwo Literackie. (wyd. oryg. 1911).

Matys, J. (2001). Uczniowie wieku dorastania jako podmiot działań biblioterapeutycznych. Biblioterapeuta, 1(13), 6-10.

Michułka, D. (2018). Bez wyjścia? O zagubieniu aksjologicznym bohaterów dziecięcych i młodzieżowych (na wybranych przykładach twórczości Ewy Przybylskiej, Barbary Kosmowskiej). Annales Universitatis Paedagogicae Cracoviensis. Studia Poetica, 6, 19-33. https://doi.org/10.24917/23534583.6.2.

Niesporek-Szamburska, B. (2017). Oswajanie przemijania - śmierć we współczesnej literaturze dziecięcej i młodzieżowej. W: K. Tałuć (red.), Literatura dla dzieci i młodzieży. Tom 5 (s. 96-119). Wydawnictwo UŚ.

Niven, J. (2015). Wszystkie jasne miejsca (D. Olejnik, tłum.). Bukowy Las.

Nowak, E. (2020). Orkan. Depresja. Egmont.

Papuzińska, J. (2002). Śmierć w literaturze dla dzieci. W: B. Tylicka, G. Leszczyński (red.), Słownik literatury dziecięcej i młodzieżowej (s. 383-384). Zakład Narodowy im. Ossolińskich.

Rogowicz, K. (2017). Literatura dla młodzieży - między popularnością a dydaktyzmem. Z Teorii i Praktyki Dydaktycznej Języka Polskiego, 26, 89-98.

Rogoż, M. (2019). Youth literature on the Polish publishing market in 2008-2018 (trends, currents, phenomena). Perspektywy Kultury, 25(2), 179-191. https://doi. org/10.35765/pk.2019.2502.13.

Skowera, M. (2017). Bezpieczna i pożyteczna kraina niedorosłości. Literatura dziecięca jako konstrukt. Jednak Ksiażki, 7, 13-30.

Slany, K. (red.). (2018). Śmierć w literaturze dziecięcej i młodzieżowej. Wydawnictwo SBP.

Stachuła, D. (reż.). (2019, 15 października). $h$. Przedstawienie na żywo w Teatrze Wielkim im. Stanisława Moniuszki, Poznań.

Suwalska, D. (2016). Czarne jeziora. Nasza Księgarnia.

Szaulińska, K. Chmielewski, D. (2016). Czarne fale. Jak radzić sobie z depresją. Poradnik dla młodzieży (wyd. 2). Fundacja III Kliniki Psychiatrii „Syntonia”.

Szulc, W. (2011). Arteterapia. Narodziny idei, ewolucja teorii, rozwój praktyki. Difin.

Szyłło, A. (2015, 8 lipca). Mamo, jestem zerem. Duży Format. Pobrane 4 maja 2021 z: https://wyborcza.pl/duzyformat/1,127290,18321428,mamo-jestem-zerem.html.

Tryzna, T. (1994). Panna Nikt. Tajemnicza powieść o dojrzewaniu. Firet.

Twenge, J. M. (2019). iGen. Dlaczego dzieciaki dorastające w sieci sa mniej zbuntowane, bardziej tolerancyjne, mniej szczęśliwe - i zupełnie nieprzygotowane do dorosłości* $i$ co to oznacza dla nas wszystkich (O. Dziedzic, tłum.). Smak Słowa. (wyd. oryg. 2017). 
Vivian, S. (2017). Fatalna lista (A. Goździkowski, tłum.). Wydawnictwo JK. (wyd. oryg. 2012).

Warwas, I., Wiktorowicz, J. (2016), Pokolenia na rynku pracy. W: J. Wiktorowicz, I. Warwas, M. Kuba, E. Staszewska, P. Woszczyk, A. Stankiewicz, J. Kliombka-Jarzyna, Pokolenia - co się zmienia? Kompendium zarządzania multigeneracyjnego (s. 19-37). Wolters Kluwer.

Wolszczak, N. (2018). Śmierć w literaturze dla dzieci i młodzieży. Fundacja „DD!KK”. 